University of Windsor

Scholarship at UWindsor

$1-10-2018$

\title{
IL-10 correlates with the expression of carboxypeptidase B2 and lymphovascular invasion in inflammatory breast cancer: The potential role of tumor infiltrated macrophages
}

\author{
Hossam T. Mohamed \\ Noura El-Husseiny \\ Eslam A. El-Ghonaimy \\ Sherif A. Ibrahim \\ Zainab A. Bazzi
}

See next page for additional authors

Follow this and additional works at: https://scholar.uwindsor.ca/biologypub

Part of the Biology Commons

\section{Recommended Citation}

Mohamed, Hossam T.; El-Husseiny, Noura; El-Ghonaimy, Eslam A.; Ibrahim, Sherif A.; Bazzi, Zainab A.; Cavallo-Medved, Dora; Boffa, Michael B.; El-Shinawi, Mohamed; and Mohamed, Mona M., "IL-10 correlates with the expression of carboxypeptidase B2 and lymphovascular invasion in inflammatory breast cancer: The potential role of tumor infiltrated macrophages" (2018). Current Problems in Cancer.

https://scholar.uwindsor.ca/biologypub/1183

This Article is brought to you for free and open access by the Department of Biological Sciences at Scholarship at UWindsor. It has been accepted for inclusion in Biological Sciences Publications by an authorized administrator of Scholarship at UWindsor. For more information, please contact scholarship@uwindsor.ca. 
Authors

Hossam T. Mohamed, Noura El-Husseiny, Eslam A. El-Ghonaimy, Sherif A. Ibrahim, Zainab A. Bazzi, Dora Cavallo-Medved, Michael B. Boffa, Mohamed El-Shinawi, and Mona M. Mohamed 


\section{Author's Accepted Manuscript}

IL-10 correlates with the expression of carboxypeptidase B2 and lymphovascular invasion in inflammatory breast cancer: The potential role of tumor infiltrated macrophages

Hossam Taha Mohamed, Noura El-Husseiny, Eslam A. El-Ghonaimy, Sherif Abdelaziz Ibrahim, Zainab A. Bazzi, Dora Cavallo-Medved, Michael B. Boffa, Mohamed El-Shinawi, Mona Mostafa Mohamed

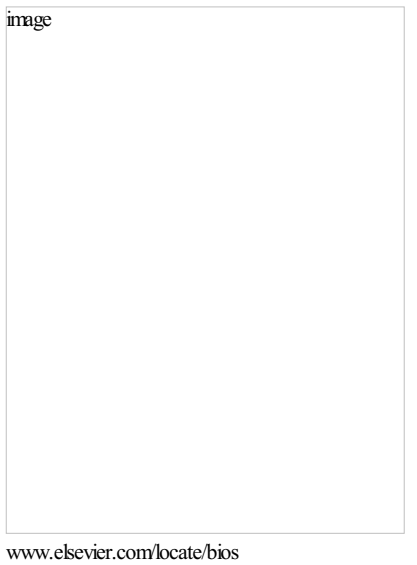

PII: $\quad$ S0147-0272(17)30120-4

DOI: $\quad$ https://doi.org/10.1016/j.currproblcancer.2018.01.009

Reference: YMCN375

To appear in: Current Problems in Cancer

Cite this article as: Hossam Taha Mohamed, Noura El-Husseiny, Eslam A. ElGhonaimy, Sherif Abdelaziz Ibrahim, Zainab A. Bazzi, Dora Cavallo-Medved, Michael B. Boffa, Mohamed El-Shinawi and Mona Mostafa Mohamed, IL-10 correlates with the expression of carboxypeptidase B2 and lymphovascular invasion in inflammatory breast cancer: The potential role of tumor infiltrated $\mathrm{m}$ a c r o $\mathrm{p} \mathrm{h}$ a $\mathrm{g}$ e $\mathrm{s}$, Current Problems

Cancer,doi:10.1016/j.currproblcancer.2018.01.009

This is a PDF file of an unedited manuscript that has been accepted for publication. As a service to our customers we are providing this early version of the manuscript. The manuscript will undergo copyediting, typesetting, and review of the resulting galley proof before it is published in its final citable form. Please note that during the production process errors may be discovered which could affect the content, and all legal disclaimers that apply to the journal pertain. 


\section{ACCEPTED MANUSCRIPT}

\section{IL-10 correlates with the expression of carboxypeptidase B2 and lymphovascular}

invasion in inflammatory breast cancer: the potential role of tumor infiltrated macrophages

Hossam Taha Mohamed ${ }^{1}$, Noura El-Husseiny ${ }^{1}$, Eslam A. El-Ghonaimy ${ }^{1}$, Sherif Abdelaziz

Ibrahim $^{1}$, Zainab A. Bazzi ${ }^{2}$, Dora Cavallo-Medved ${ }^{3}$, Michael B. Boffa ${ }^{2}$, Mohamed ElShinawi ${ }^{4,5}$ and Mona Mostafa Mohamed ${ }^{1,5} *$

${ }^{1}$ Department of Zoology, Faculty of Science, Cairo University, Giza, 12613, Egypt.

${ }^{2}$ Department of Biochemistry, University of Western Ontario, London, Ontario, N6A 3K7, Canada.

${ }^{3}$ Department of Biological Sciences, University of Windsor, Ontario, N9B3P4, Canada.

${ }^{4}$ Department of General Surgery, Faculty of Medicine, Ain Shams University, Cairo, 11566, Egypt.

${ }^{5}$ Breast-Gynecological International Cancer Society, Cairo, Egypt.

\section{*Corresponding author:}

Mona Mostafa Mohamed, Ph.D.

Department of Zoology, Faculty of Science, Cairo University, 12613, Giza, Egypt. Email: mmostafa@sci.cu.edu.eg

Tel. +2-02-35676720

Fax. +2-02-35727556

\section{Abstract}

\section{Background:}

Pro-carboxypeptidase B2 (pro-CPB2) or thrombin-activatable fibrinolysis inhibitor (TAFI) is a glycoprotein encoded by the $C P B 2$ gene and deregulated in several cancer types, including breast cancer. Thrombin binding to thrombomodulin (TM), encoded by $T H B D$, is important for TAFI activation. $C P B 2$ gene expression is influenced by genetic polymorphism and cytokines such as interleukin 10 (IL-10). Our previous results showed that tumor infiltrating monocytes/macrophages $\left(\mathrm{CD} 14^{+} / \mathrm{CD} 16^{+}\right)$isolated from inflammatory breast cancer (IBC) patients' secrete high levels of IL-10. The aim of the present study is to test genetic polymorphism and expression of $C P B 2$ in healthy breast tissues and carcinoma tissues of 


\section{ACCEPTED MANUSCRIPT}

non-IBC and IBC patients. Furthermore, to investigate whether IL-10 modulates the expression of CPB2 and THBD in vivo and in-vitro.

\section{Materials and methods}

We tested $C P B 2$ Thr325Ile polymorphism using restriction fragment length polymorphism, (RFLP) technique in healthy and carcinoma breast tissues. The mRNA expression of $C P B 2$, THBD and IL10 were assessed by RT-qPCR. Infiltration of $\mathrm{CD}_{1} 4^{+}$cells was assessed by immunohistochemistry. We investigated the correlation between infiltration of $\mathrm{CD} 14^{+}$cells and expression of ILIO and CPB2. Furthermore, we correlated ILIO expression with the expression of both $C P B 2$ and $T H B D$ in breast carcinoma tissues. Finally, we validated the role of recombinant IL-10 in regulating the expression of $C P B 2$ and $T H B D$ using different breast cancer cell lines.

\section{Results:}

Our data showed that $C P B 2$ genotypes carrying the high-risk allele [Thr/Ile (CT) and Ile/Ile (TT)] were more frequent in both IBC and non-IBC patients compared to control group. $C P B 2$ genotypes did not show any statistical correlation with $C P B 2 \mathrm{mRNA}$ expression levels or patients' clinical pathological properties. Interestingly, $C P B 2$ and ILIO expression were significantly higher and positively correlated with the incidence of $\mathrm{CD}_{14}{ }^{+}$cells in carcinoma tissues of IBC as compared to non-IBC. On the other hand, THBD expression was significantly lower in IBC carcinoma versus non-IBC tissues. Based on molecular subtypes, $C P B 2$ and IL10 expression were significantly higher in triple negative (TN) as compared to hormonal positive (HP) carcinoma tissues of IBC. Moreover, CPB2 expression was positively correlated with presence of lymphovascular invasion and the expression of ILIO in carcinoma tissues of IBC patients. Furthermore, recombinant human IL-10 stimulated $C P B 2$ expression in SUM-149 (IBC cell line) but not in MDA-MB-231 (non-IBC cell line), while there was no significant effect $T H B D$ expression. 


\section{Conclusion:}

Carcinoma tissues of IBC patients are characterized by higher expression of $C P B 2$ and lower expression of $T H B D$. Moreover, $C P B 2$ positively correlates with ILIO mRNA expression, incidence of $\mathrm{CD} 14^{+}$cells and lymphovascular invasion in IBC patients. IL-10 stimulated $C P B 2$ expression in TN-IBC cell line suggests a relevant role of $C P B 2$ in the aggressive phenotype of IBC.

\section{Keywords:}

Inflammatory breast cancer, carboxypeptidase B2, thrombin-activatable fibrinolysis inhibitor, interleukin-10, thrombomodulin, macrophages, lymphovascular invasion.

\section{Introduction:}

Inflammatory breast cancer (IBC) is a particularly aggressive and highly metastatic form of breast cancer. The progression of IBC is associated with (lymph) angiogenesis, and a pronounced ability for lymphovascular invasion and formation of lymphatic tumor emboli that promote metastasis and dissemination to different organs [1-3]. In addition, the overall survival (OS) and breast cancer-specific mortality (BCSM) of IBC are higher among patients with a triple negative (TN) molecular subtype as compared to others [4]. In this regard, novel therapeutic options that target TN-IBC molecular subtype should be considered [5].

Case report studies from different countries showed that IBC may be associated with thrombosis. For instance, a 54-year-old woman initially diagnosed with spontaneous brachial, axillary, and subclavian venous thrombosis was also found to have late stage IBC [6]. Another study showed that an IBC patient presented early with arm lymphoedema and venous thromboembolism (VTE) [7]. Serra and colleagues reported that axillary vein thrombosis may be considered as the first clinical manifestation of IBC [8]. Indeed, VTE increases the rate of morbidity and mortality among cancer patients. The incidence of VTE 


\section{ACCEPTED MANUSCRIPT}

has increased in the past 2 decades [9], and $20 \%$ to $30 \%$ of VTE cases were found to be associated with the development of cancer [10]. Studying the relationship between thromboembolism and cancer may provide novel insights for early diagnosis of the disease [7].

One of the proteins associated with the formation of VTE is pro-carboxypeptidase B2 (proCPB2), also known as thrombin activatable fibrinolysis inhibitor (TAFI) [11]. pro-CPB2 is a glycoprotein, encoded by $C P B 2$, synthesized mainly in the liver as a $60-\mathrm{kDa}$ zymogen, and proteolytically activated by plasmin, thrombin or the thrombin-thrombomodulin complex [12]. The active form pro-CPB2, known as CPB2 or TAFIa, is a 35-kDa basic carboxypeptidase [13]. CPB2 inhibits lysis of the fibrin clot by removing C-terminal lysine residues from partially-degraded fibrin, attenuating plasminogen activation and ultimately fibrinolysis [14].

Previous studies showed that pro-CPB2 protein might be associated with poor prognosis of cancer. For instance, pro-CPB2 is highly secreted from lung carcinoma cells and plays a crucial role in the pathogenesis of thrombotic disorders in lung cancer patients [15]. Another study reported high pro-CPB2 levels in the advanced colorectal cancer patients as compared to those showing localization of cancer cells in the colon [16]. Serum pro-CPB2 levels are significantly higher in breast cancer patients as compared to healthy control. High levels of pro-CPB2 may be associated with thrombotic disorders in breast cancer patients [17]. A Chinese study suggested that $C P B 2$ Thr325Ile polymorphism might be considered a risk factor for development of breast cancer in Chinese Han populations [18]. A pilot study assessing pro-CPB2 level in plasma of Egyptian breast cancer patients showed an increase in pro-CPB2 plasma level that is correlated with advanced stages, poor prognosis and high risk of disease recurrence. Furthermore, CPB2 Thr325Ile polymorphism was associated with the development of breast cancer in Egyptian population [19]. 


\section{ACCEPTED MANUSCRIPT}

The anticoagulant/antifibrinolytic factor thrombomodulin (TM) encoded by $T H B D$ gene is a type 1 transmembrane glycoprotein $[20,21]$ that has the ability to regulate inflammation and tumor promotion [22-25]. THBD expression in carcinoma tissues is associated with less advanced stage and a better prognosis in several cancers [26-28]. Thrombin binding to TM is important for the physiological activation of pro-CPB2 to $\mathrm{CPB} 2$ and has been shown to be responsible for the anti-metastatic effects of TM [29]. Furthermore, CPB2 has been shown to inhibit cell invasion and motility of breast carcinoma cells [30].

Interleukin 10 (IL-10) is "double-edged sword" cytokine as it displays both pro and antitumor activities [31]. It is suggested that IL-10 is expressed at a higher level by metastatic cancer cells to down regulate the inflammatory response of cell-mediated immunity [32]. IL10 levels in serum of breast cancer patients were associated with disease initiation and progression [33]. A recent study reported higher expression level of IL-10 in the examined breast cancer tissue, and increased IL-10 expression associated with poor prognosis [34]. Indeed, the tumor microenvironment of IBC patients is characterized by the activation of different signaling pathways such as NF- $\mathrm{BB}, \mathrm{COX}-2$, and JAK/STAT, which induce the expression and secretion of various pro- and anti-inflammatory cytokines $[35,36]$. Our previous studies showed that IL-10 is over expressed by tumor-associated macrophages isolated from IBC patients $[35,36]$. Recently we found that the expression of ILIO in IBC carcinoma tissues correlate with GCC haplotypes $(-1082 \mathrm{~A} / \mathrm{G},-819 \mathrm{~T} / \mathrm{C}$, and $-592 \mathrm{~A} / \mathrm{C})$ in the gene promoter region [37].

Many studies have shown a differential role for cytokines including IL-10 in regulating the expression of $C P B 2$ in different cell lines. For example, the treatment of human hepatocellular carcinoma cell line, HepG2, with TNF $\alpha$ or IL-6 in combination with IL-1 $\beta$, or bacterial lipopolysaccharide (LPS) for 24-48 h decreases expression of pro-CPB2 protein by two-fold. Additionally, IL-10 increases the expression of $C P B 2$ mRNA in HepG2 cell line 


\section{ACCEPTED MANUSCRIPT}

[38]. In the present study, we examined the mRNA expression level of $C P B 2, T H B D$ and IL10 in non-IBC and IBC carcinoma tissues, and whether the CPB2 Thr325Ile polymorphism affects expression of $C P B 2$. Furthermore, we investigated the effects of IL-10 on the expression of $C P B 2$ and THBD in vivo and in-vitro.

\section{Materials and Methods:}

\section{Patients and Samples}

For patient enrolment we obtained an institutional Review Board (IRB) approval from the ethics committee of Faculty of Medicine, Ain Shams University, Egypt. Patients were diagnosed with non-IBC or IBC by clinical ultrasound examination, mammography and trucut biopsy [36, 39]. A total of 135 breast cancer patients (91 non-IBC and 44 IBC) and 50 healthy volunteers were enrolled in the present study. Carcinoma tissues were obtained during modified radical mastectomy (MRM). Normal breast tissues were obtained from healthy volunteers undergoing mammoplasty. All enrolled healthy volunteers and breast cancer patients signed informed consent that agrees with publication of anonymous data.

\section{Quantitative real-time Polymerase chain reaction (RT-qPCR)}

Total RNA was extracted from $30 \mathrm{mg}$ of fresh breast tissues (normal and carcinoma) and

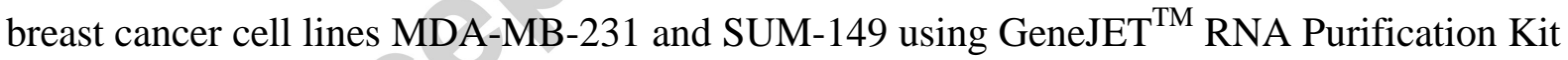
(Thermo scientific, ON, Canada). RNA concentration was measured using Infinite ${ }^{\circledR} 200$ PRO NanoQuant (Tecan, Männedorf, Zürich, Switzerland) and $1 \mu \mathrm{g}$ was reversed transcribed into complementary DNA using RevertAid First Strand cDNA Synthesis Kit (Thermo scientific, ON, Canada). Quantitative PCR was performed as described before [40, 41] via using StepOnePlus 96 well device (Applied Biosystems, San Francisco, CA, USA) and in a $25 \mu 1$ total volume of $12.5 \mu \mathrm{l}$ SYBR green master mix (Applied Biosystems, Darmstadt, Hesse, Germany), $0.5 \mu 1$ of each CPB2 upstream 5'-GCTGCCGGAGCGTTACAT-3' and 


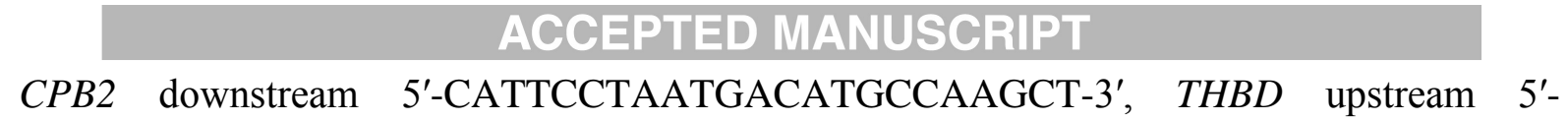

CCCTGAACAAGAAT TGGAAGCT $-3^{\prime}$ and THBD downstream 5'- GGAGCCTAGGATT CTGCATTTCTA-3', and ILIO upstream 5'- GCCACCCTGATGTCTCAGTT -3' and ILIO downstream 5'- GTGGAGCAGGTGAAGAATGC -3' primers (10 pmol/ $\mu \mathrm{l}), 2.5 \mu \mathrm{l}$ of cDNA and $8 \mu \mathrm{l}$ of RNase free water. Reaction thermal profile started with initial denaturation at $95^{\circ} \mathrm{C}$ for $10 \mathrm{~min}$, then followed by 40 cycle of $94^{\circ} \mathrm{C}$ for $15 \mathrm{sec}$ and $60^{\circ} \mathrm{C}$ for $1 \mathrm{~min}$. Amplification specificity was verified using melting curve analysis and $2 \%$ agarose gel electrophoresis of the PCR products. Data were analyzed using the $2^{-\Delta \Delta \mathrm{Ct}}$ method after normalization to glyceraldehyde 3-phosphate dehydrogenase (GAPDH) (Qiagen, Valencia, CA, USA) (10 pmol $\mid \mu l)$.

Restriction Fragment Length Polymorphism (RFLP)-PCR assay for CPB2 (Thr325Ile) polymorphism

DNA was extracted from breast tissues by using GeneJET ${ }^{\mathrm{TM}}$ Genomic DNA purification Kit (Thermo scientific, ON, Canada). The RFLP-PCR assay was carried out in a $25 \mu 1$ total volume using $1 \mu 1$ of each designed CPB2 upstream 5'-TTCAAAGCTGCACATTAACTG-3' and $C P B 2$ downstream 5'-CTTTAGTAGCTCAAA GTTCTC-3' primers (10 pmol/ $\mu \mathrm{l}), 3 \mu \mathrm{l}$ of DNA extract (250 ng DNA), $12.5 \mu$ of EmeraldAmp ${ }^{\circledR}$ MAX PCR green master mix and $7.5 \mu \mathrm{l}$ of free RNase water. The PCR thermal profile started with an initial denaturation at 94 ${ }^{\circ} \mathrm{C}$ for $5 \mathrm{~min}$, followed by 35 cycles at $94^{\circ} \mathrm{C}$ for $45 \mathrm{sec}, 54^{\circ} \mathrm{C}$ for $1 \mathrm{~min}$, and $72{ }^{\circ} \mathrm{C}$ for $45 \mathrm{sec}$, followed by terminal extension at $72{ }^{\circ} \mathrm{C}$ for $10 \mathrm{~min}$. The PCR product has an expected size of 200 bp. Following PCR, the PCR product was digested by SpeI restriction enzyme (10U) (Takara, Dalian, China) for $2 \mathrm{~h}$ at $37^{\circ} \mathrm{C}$ and subject to agarose gel electrophoresis. The digest PCR products migrated bands were visualized on 2\% agarose gels by using iBox Scientia 615 Imaging System (UVP Upland, CA, USA). Samples with CC genotype showed digestion with SpeI was represented by a band at $100 \mathrm{bp}$. Samples with TT genotype did not show 


\section{ACCEPTED MANUSCRIPT}

digestion with SpeI was represented by a band at 200 bp. Samples with both genotypes CT bands at $100 \mathrm{bp}$ and $200 \mathrm{bp}$ were detected as described before [42]. Twenty percent of samples were re-genotyped in separate runs to exclude the possibility of false genotyping.

\section{Immunohistochemistry}

Immunohistochemical (IHC) staining was performed on $4 \mu \mathrm{m}$ thick paraffin embedded tissue sections as we described before [43] using antibodies against CD14 (1:50) (Chemicon, Temecula, CA, USA) and CD68 (1:50) (DakoCytomation, Glostrup, Denmark). Staining was achieved by adding $100 \mu \mathrm{l}$ of $\mathrm{DAB}+$ chromogen diluted 1:50 in substrate buffer [EnVision+ Dual Link System-HRP (DAB+)] for $10 \mathrm{~min}$. Finally, tissue specimens were rinsed three times in phosphate buffer saline (PBS), the nuclei were counterstained with hematoxylin and mounted using Permount ${ }^{\circledR}$ for microscopic examination. The stained area fractions were calculated using image $\mathbf{J}$ software (National Institutes of Health, Bethesda, MD, USA).

\section{Sodium dodecyl sulfate polyacrylamide gel electrophoresis and immunoblotting}

Protein content of fresh breast carcinoma tissues lysates was assessed by Bradford assay [44]. Equal concentration of tissue protein lysates $(30 \mu \mathrm{g} / \mathrm{well})$ were subjected to $10 \%$ SDS-PAGE, followed by transfer to Polyvinylidene fluoride (PVDF) membrane (Millipore, Darmstadt, Germany). The membranes were blocked for $1 \mathrm{~h}$ with $5 \%$ non-fat dry milk in TBS- $0.5 \%$ Tween 20 , followed by incubation overnight at $4{ }^{\circ} \mathrm{C}$ with anti-IL-10 (R\&D systems, MN, USA) (1:100) then washed and incubated for $1 \mathrm{~h}$ with 1:10000 diluted peroxidase-labeled goat anti-rabbit secondary antibody. After washing, the bands were visualized by using Pierce ECL immuno-blotting substrate (Thermo Fisher Scientific, Rockford, IL, USA). Signals representing protein bands were captured with the iBox Scientia 615 Imaging System (UVP Upland, CA, USA). Visualized protein bands were analyzed by ImageJ (National Institutes of Health, USA.) software and quantified relativity to $\beta$-tubulin as loading control [44]. 


\section{ACCEPTED MANUSCRIPT}

Effect of recombinant human IL-10 on the expression of $C P B 2$ by breast cancer cell lines

We studied the effect of recombinant human IL-10 on MDA-MB-231 (non-IBC) and SUM149 (IBC) cell lines (gift from Dr. Bonnie Sloane, Department of Pharmacology, Wayne State University, Detroit, MI, USA). Cell lines were cultured as previously described [36, 45]. MDA-MB-231 and SUM-149 cells were seeded at the density of $\left(3.5 \times 10^{5} /\right.$ well $)$ in six well plate and incubated at $37^{\circ} \mathrm{C}$ and $5 \% \mathrm{CO}_{2}$ for $24 \mathrm{~h}$ in appropriate complete media, Ham's F.12 containing 5\% FBS and DMEM containing 10\% FBS for SUM149 and MDA-MB-231, respectively $[45,46]$. Cultured media were removed and cells incubated in serum free media conditioned with recombinant IL-10 (R\&D systems, Minneapolis, Minnesota, USA) at concentrations of 100, 200 and $400 \mathrm{ng} / \mathrm{ml}$ for $24 \mathrm{~h}$ [36]. Then cells were washed twice with cold PBS and total RNA extracted.

\section{Statistical Analysis}

Data were expressed as mean \pm standard deviation (SD). Statistical difference between groups was assessed by Student's t-test and Chi square test. $\mathrm{P}$ values $<0.05$ were considered to be statistically significant. To determine the association between CPB2 Thr325Ile polymorphism and the development of breast cancer we used Hardy-Weinberg equilibrium to compare the genotype frequencies in cancer patients and the healthy control group. Logistic regression was used to calculate the odds ratios (OR) and $95 \%$ confidence interval (CI) to estimate the relative association between breast cancer development and a particular allele and genotype using SNPstat software [47, 48]. Correlation was assessed by Pearson's correlation coefficient using SPSS 22.0 software. 


\section{ACCEPTED MANUSCRIPT}

\section{Results:}

\section{Clinical and pathological characterization of breast cancer patients}

Clinical and pathological characterization of non-IBC and IBC patients was described in Table 1. Statistical analysis showed that IBC patients were characterized with significantly larger tumor size $(p=0.003)$ in comparison with non-IBC patients. Moreover, the status of lymph node metastasis and lymphovascular invasion in IBC patients was significantly higher ( $p=0.002$ and 0.001 , respectively) than non-IBC patients.

Incidence of CPB2 genotypes carrying the high-risk allele [Thr/Ile (CT) and Ile/Ile (TT)] was higher in breast cancer patients compared to healthy volunteers

The genotypes and alleles distributions for the CPB2 Thr325Ile polymorphism are presented in Table 2. The genotype distribution of both studied groups' fits the Hardy-Weinberg equilibrium $(p>0.05)$. The incidence of $C P B 2$ genotypes carrying the high-risk allele [Thr/Ile (CT) and Ile/Ile (TT)] was significantly higher $(p=0.003)$ in breast cancer patients in comparison with healthy volunteers (OR: 0.32; [95\% CI: 0.16-0.64]; $P=0.001$ ). We did not detect a statistically significant difference in the incidence of $C P B 2$ genotypes carrying the high-risk allele [Thr/Ile (CT) and Ile/Ile (TT)] between non-IBC and IBC patients. CPB2 mRNA expression level did not show a statistical correlation with the incidence of $C P B 2$ genotypes carrying the high-risk allele [Thr/Ile (CT) and Ile/Ile (TT)] in each of healthy volunteers and breast cancer patients or even among patient non-IBC and IBC subgroups (Supplementary Table 1). In addition, there was no association between the incidence of CPB2 genotypes carrying the high-risk allele [Thr/Ile (CT) and Ile/Ile (TT)] and patients' clinical pathological properties including tumor grade, tumor size, lymphovascular invasion, lymph node status, expression of ER, PR and Her-2 in each of non-IBC and IBC patient groups (Supplementary Tables $2 \& 3$ ). 


\section{ACCEPTED MANUSCRIPT}

CPB2 mRNA expression level is higher in triple negative (TN) breast carcinoma tissues of non-IBC and IBC patients in comparison to hormonal positive (HP), and positively correlates lymphovascular invasion in IBC patients

Carcinoma tissues obtained during MRM showed a significant $(p=0.001)$ higher $C P B 2$ mRNA expression level compared to normal breast tissues obtained from mammoplasty of healthy volunteers (Figure 1A). CPB2 mRNA expression level was significantly ( $p=0.003$ ) higher in IBC compared to non-IBC tissue (Figure 1B). Interestingly, carcinoma tissues of TN breast cancer patients expressed significantly higher level of $C P B 2 \mathrm{mRNA}$ compared to HP patients in both non-IBC and IBC groups ( $p=0.03$ and 0.02 , respectively) (Figure $1 \mathrm{C} \&$ D).

\section{Low expression of THBD mRNA in IBC compared to non-IBC carcinoma tissues}

Although there was a non-significant difference in $T H B D$ mRNA expression between healthy and breast tissues (Figure $1 \mathrm{E})$, there was a significantly $(p=0.02)$ lower level in IBC compared to non-IBC tissue (Figure $1 \mathrm{~F}$ ). On the other hand, there was no significant difference in the expression of THBD mRNA expression level in carcinoma tissues of TN compared to HP patients in both non-IBC and IBC groups (Figure $1 \mathrm{G} \mathrm{\&} \mathrm{H}$ ). The THBD mRNA expression level showed non-significant correlation with $C P B 2$ mRNA expression level in both non-IBC and IBC patients (Supplementary Table 4). With respect to the relationship between $T H B D$ mRNA expression and clinical pathological data, statistical analysis detected significant inverse correlations with tumor grade $(\mathrm{r}=-0.684, p=0.02)$ and lymph node status $(\mathrm{r}=-0.711, p=0.005)$ in both non-IBC and IBC patients.

Expression level of IL-10 is higher in triple negative compared to hormonal positive IBC patients and positively correlates with $C P B 2$ mRNA expression 


\section{ACCEPTED MANUSCRIPT}

IL10 mRNA is significantly higher $(p=0.01)$ in breast carcinoma as compared to healthy breast tissues (Figure 2A). Furthermore, IL10 mRNA expression was significantly ( $p=0.02$ ) higher in IBC compared to non-IBC (Figure 2B). According to molecular subtypes of patients, we did not detect significant differences in IL10 mRNA expression in TN compared to $\mathrm{HP}$ in the non-IBC sub-group (Figure $2 \mathrm{C}$ ). On the other hand, in the IBC sub-group IL10 mRNA expression level was significantly higher in $\mathrm{TN}(p=0.03)$ as compared to HP carcinoma tissues (Figure 2D). In the same manner, IL-10 protein levels were significantly $(p=0.03)$ higher in IBC as compared to non-IBC tissue (Figure 2E). IL-10 protein levels did not differ between TN and HP in non-IBC carcinoma tissues (Figure 2F and 2G), but was significantly higher in TN as compared to HP IBC carcinoma tissues (Figure $2 \mathrm{H}$ and 2I). IL10 mRNA expression do not correlate with mRNA expression of CPB2 in non-IBC patients group. However, we detected a significantly positive correlation between mRNA expression of $C P B 2$ and $I L 10$ in $\mathrm{TN}(\mathrm{r}=0.783, p=0.004)$ and $\mathrm{HP}(\mathrm{r}=0.625, p=0.01)$ in the IBC patients patient subgroups (Supplementary Table 4).

\section{Expression of $C P B 2$ and $I L 10$ correlate with the presence of lymphovascular invasion in}

\section{IBC}

$C P B 2$ mRNA expression level showed no correlation with patients' clinical pathological data including tumor grade, tumor size and lymph node status in both non-IBC and IBC patients. However, $C P B 2$ mRNA expression levels significantly $(\mathrm{r}=0.766, p=0.004)$ correlated with the presence of lymphovascular invasion in IBC but not non-IBC patients (Figure $3 \mathrm{~A} \& \mathrm{~B}$ ). In addition, mRNA expression of $I L 10$ was significantly $(\mathrm{r}=0.831, p=0.002)$ and positively correlates with lymphovascular invasion in and IBC patients (Figure 3C).

CPB2 and IL10 mRNA positively correlate with infiltration of $\mathrm{CD}^{+} 4^{+}$cells in IBC carcinoma tissues 


\section{ACCEPTED MANUSCRIPT}

Our previous results showed that $\mathrm{CD} 14^{+}$cells highly infiltrate the carcinoma tissues of IBC as compared to non-IBC patients. However, we did not detect a significant difference in the infiltration of $\mathrm{CD}^{+} 8^{+}$cells between these two patient groups. Furthermore, we showed that $\mathrm{CD}_{14}{ }^{+}$cells isolated from tumor microenvironment of IBC patients highly secrete IL-10 as compared to non-IBC [36]. Since IL-10 regulates the expression of CPB2 [38], we assessed the correlation between infiltration of CD14+ cells and the expression of IL1O and CPB2 in IBC carcinoma tissues. Analysis of IHC staining revealed high infiltration of $\mathrm{CD}_{14}{ }^{+}$in IBC carcinoma tissues as compared to non-IBC (Fig. 4 A \& B). Expression of CPB2 and IL10 significantly $(\mathrm{r}=0.605, p=0.05$ and $\mathrm{r}=0.753, p=0.01$, respectively) and positively correlate with the infiltration of $\mathrm{CD} 14^{+}$cells in IBC carcinoma tissues (Fig. $4 \mathrm{C} \& \mathrm{D}$ ). However, we did not find any correlation between $C P B 2$ and IL10 mRNA expression and infiltration of $\mathrm{CD} 68^{+}$cells in either non-IBC or IBC carcinoma tissues (data not shown).

\section{Recombinant IL-10 stimulates the expression of CPB2 mRNA in IBC cell line SUM149}

To validate our findings using an in vitro system, we stimulated MDA-MB-231, a TN-nonIBC cell line, and SUM149, a TN-IBC cell line, with varying concentrations of recombinant IL-10 $(100,200$ and $400 \mathrm{ng} / \mathrm{ml})$ for $24 \mathrm{~h}$. The mRNA extracted from the treated cells was subjected to $C P B 2$ and $T H B D$ RT-qPCR analysis. Results showed that treatment with IL-10 did not significantly alter $C P B 2$ expression in MDA-MB-231 cells, while $C P B 2$ expression levels in SUM149 cells were significantly induced $(p=0.04,0.03 \& 0.01)$ in response to different concentrations of recombinant IL-10 (100, 200 and 400 ng/ml, respectively) (Figure 5A). On the other hand, recombinant IL-10 did not significantly alter $T H B D$ expression in either MDA-MB-231or SUM149 cell lines (Figure 5B). 


\section{ACCEPTED MANUSCRIPT}

\section{Discussion:}

IBC is the most lethal form of breast cancer and is characterized by phenotypes that differ from other breast cancer. Several studies including ours have shown that IBC disease displays unusual biological properties. These include rapid progression, metastasis and production of a unique repertoire of growth factors, cytokines and chemokines, high infiltration of macrophages/monocytes $\left(\mathrm{CD} 14^{+}\right.$cells), and detection of multiple viral DNAs compared to non-IBC $[36,49,50]$. Recent studies have also shown that VTE is more common in IBC patients $[6,8]$. Moreover, high plasma levels of pro-CPB2, a zymogen encoded by $C P B 2$, are a risk factor for VTE [11].

In the present study, we found that the incidence of $C P B 2$ genotypes carrying the allele [Thr/Ile (CT) and Ile/Ile (TT)] was significantly higher in breast cancer patients compared to control population. However, we did not detect any correlation between the incidence of genotypes carrying the high-risk allele [Thr/Ile (CT) and Ile/Ile (TT)] and tumor grade, tumor size, lymph node status, ER status, PR status and Her-2 status in either non-IBC or IBC patients. In agreement with this finding, a study conducted by Fawzy and colleagues found that incidence of $C P B 2$ genotypes carrying Thr/Ile (CT) and Ile/Ile (TT) allele was higher in breast cancer patients as compared to healthy patient group, and positively correlates with pro-CPB2 antigen levels in peripheral blood of Egyptian breast cancer patients. Moreover, they found that the (Thr/Thr) genotype corresponds to the highest level of plasma pro-CPB2 antigen and the (Ile/Ile) genotype corresponds to the lowest level of plasma pro-CPB2 antigen [19]. We found the $C P B 2$ mRNA expression was higher in breast carcinoma tissues as compared to normal breast tissues. In addition, $C P B 2 \mathrm{mRNA}$ expression was higher in IBC than non-IBC carcinoma tissues. We did not detect any correlation between the incidence of $C P B 2 \mathrm{Thr} 325 \mathrm{Il}$ e different genotypes and $C P B 2$ mRNA in breast carcinoma tissues of either non-IBC or IBC patients. 


\section{ACCEPTED MANUSCRIPT}

The triple negative breast cancer (TNBC) patients currently have no targeted therapies and are characterized by poor disease prognosis and low survival rate [51].

We found that $C P B 2$ mRNA expression was higher in the carcinoma tissues of TNBC patients compared to HP patients. On the other hand, female sex steroid hormones were found to decrease expression of $C P B 2 \mathrm{mRNA}$ and pro-CPB2 protein in human hepatoma cell line, in a mechanism mediated by phosphatidylinositol 3-kinase and Akt signaling pathway and independent of the estrogen receptor [52].

Our results showed that $C P B 2$ expression in breast carcinoma tissues did not show any significant correlation with tumor size, tumor grade, lymph node involvement, expression of hormone receptors (ER/PR) and HER-2. However CPB2 expression positively correlated with presence of lymphovascular invasion in IBC and not in non-IBC patients. Since lymphovascular invasion is essential for metastasis, this suggests a role for pro-CPB2 in metastasis. Previous studies have shown an association between pro-CPB2 and metastasis in Chinese breast cancer patients [18], and with poor prognosis in Egyptian breast cancer patients [19].

The activation of pro-CPB2 depends on the concentration of TM [53]. We found that mRNA expression of $T H B D$ was lower in the carcinoma tissues of IBC as compared to non-IBC patients. However, the level of $C P B 2$ mRNA was higher in the carcinoma tissues of IBC patients; although this may not result in functional CPB2 enzyme due to decreased expression of $T H B D$ in the tumor microenvironment. At the molecular level, THBD mRNA expression was not correlated with $C P B 2$ mRNA expression in the carcinoma tissues of either non-IBC or IBC patients. The THBD mRNA expression level found to be significantly and inversely correlated with tumor grade and lymph node status in both non-IBC and IBC patients. This is in agreement with a previous study of bladder cancer, which demonstrated that decreased TM expression level is a predictor of aggressiveness in advanced bladder cancer [54]. TM 


\section{ACCEPTED MANUSCRIPT}

expression was also shown to be decreased in human prostate cancer cell lines, DU-145, LNCaP and PC-3 as compared to normal prostate epithelial cells PrEC [55].

Our results also demonstrate that IL10 expression was higher in breast carcinoma tissue in comparison with healthy tissues. This is in agreement with a previous study showing higher expression levels of IL-10 in breast cancer tissues [34]. Herein, the expression of IL-10 was higher in IBC as compared to non-IBC carcinoma tissues. Moreover, the IL-10 expression level was higher in TN-IBC versus HP-IBC tissues. This, in part, supports previous study showing that IL-10 is over expressed in ER-negative breast tumors as compared to ERpositive carcinoma tissues [56].

It is well established that the tumor microenvironment plays an essential role in breast cancer progression. Higher infiltration of TAMs in breast carcinoma tissues of IBC is associated with the secretion of cytokines and growth factors such as IL-10, IL-8, tumor necrosis factoralpha (TNF- $\alpha$ ) and CC-chemokine ligand 2 (CCL2) that enhance motility, invasion and the aggressive properties of IBC $[36,57]$. However, the source of $C P B 2 \mathrm{mRNA}$ in the breast cancer remains unclear. $C P B 2$ mRNA and pro-CPB2 protein found to be expressed by macrophages [42]. In the present study, IL1O expression was positively correlated with infiltration of macrophages in carcinoma and lymphovascular invasion in IBC patients. This is in agreement with previous study on lung cancer showed that higher mRNA expression of IL10 by TAMs was associated with advanced stage, tumor size, lymph node metastasis and lymphovascular invasion [58]. Our results showed that infiltration of $\mathrm{CD}_{14}{ }^{+}$cells positively correlates with mRNA expression of ILIO and $C P B 2$ in IBC but not in non-IBC carcinoma tissues.

$C P B 2$ gene expression is regulated by various cytokines. For instance in acute coronary syndrome (ACS) there is a positive correlation between IL-1 $\beta$, IL-6, TNF- $\alpha$ and serum proCPB2 concentration [59]. TNF- $\alpha$, IL-6 in combination with IL-1 $\beta$ and lipopolysaccharide 


\section{ACCEPTED MANUSCRIPT}

(LPS) decrease transcription of mRNA/pro-CPB2 protein levels by approximately two-fold, while IL-10 increased pro-CPB2 protein levels by two-fold in a mechanism modulated by binding of tristetraprolin (TTP) to the CPB2 3'-UTR, [38]. Similarly, we detected a positive correlation between $I L 10$ and $C P B 2$ expression in the carcinoma tissues of non-IBC and IBC patients as compared to normal breast tissues of healthy control. These results were validated in vitro. We found that IL-10 significantly upregulated expression of the $C P B 2$ in the IBC cell line SUM-149 but not in non-IBC cell line MDA-MB-231, while no significant effect appeared on $T H B D$ expression in either cell lines. Our results suggest that macrophage infiltration and expression of ILIO in IBC carcinoma tissues may induce the expression of CPB2.

In conclusion, our study showed that CPB2 and IL10 expression are highly expressed in carcinoma tissues, and that this increase correlates with lymphovascular invasion in IBC patients. Furthermore, we demonstrated that the TN patients are characterized by higher expression of $C P B 2$ as compared to HP patients in each of non-IBC and IBC groups. THBD expression is down regulated in IBC as compared to non-IBC carcinoma tissues. A potential mechanism linking patient tumor characteristics with increased $C P B 2$ expression may be through the high infiltration of $\mathrm{CD} 14^{+}$cells and IL10 in carcinoma tissues of IBC patients. Thus CPB2 may be regulated by IL-10 in vivo, as demonstrated by the in vitro data. Further studies are needed to fully understand the role of $C P B 2$ expression, and pro-CPB2 activation by the thrombin-TM complex, in the etiology of IBC. 


\section{ACCEPTED MANUSCRIPT}

\section{Acknowledgments:}

The experiments were conducted at Cancer Biology Research Laboratory, Faculty of Science, Cairo University, Giza, Egypt from January 2015 till January 2017. Authors are supported by Avon Foundation-USA (MMM), Cairo University Scientific Research Sector, Giza, Egypt (SAI and MMM), the Windsor Essex Cancer Centre Foundation (MBB), and the Natural Sciences and Engineering Research Council of Canada (MBB).

\section{Conflict of Interest Statement}

The authors declare that the research was conducted in the absence of any commercial or financial relationships that could be construed as a potential conflict of interest.

\section{Sources of support:}

Authors are supported by Avon Foundation-USA (MMM), Cairo University Scientific Research Sector (SAI and MMM), and the Windsor Essex Cancer Centre Foundation (MBB).

\section{Research Ethical approval for Human Participants}

For breast cancer patients and healthy volunteer enrolment in this study we obtained Ethical approval from the Institutional Review Board (IRB\#00006379), Faculty of Medicine, Ain Shams University, Egypt.

\section{Author's contribution:}

HTM, EAG, NEH, SAI and MMM carried out the experiments. MSH recruited patients' provided the clinical diagnosis, grouped/sub-grouped patients and prepared of clinical pathological data. HTM, SAI, MSH, DCM and MMM performed data analysis and interpretation of results. HTM, SAI, ZAB, DCM, MBB and MMM made substantial contributions to concept and design of experiments. HTM and MMM drafted the manuscript. All authors have read, revised and approved the manuscript. 


\section{ACCEPTED MANUSCRIPT}

\section{References:}

1. Van Laere, S.J., G.G. Van den Eynden, I. Van der Auwera, M. Vandenberghe, P. van Dam, E.A. Van Marck, K.L. van Golen, P.B. Vermeulen, and L.Y. Dirix, Identification of cell-of-origin breast tumor subtypes in inflammatory breast cancer by gene expression profiling. Breast Cancer Res Treat, 2006. 95(3): p. 243-55.

2. Cristofanilli, M., A.U. Buzdar, and G.N. Hortobagyi, Update on the management of inflammatory breast cancer. Oncologist, 2003. 8(2): p. 141-8.

3. Van Laere, S., I. Van der Auwera, G.G. Van den Eynden, S.B. Fox, F. Bianchi, A.L. Harris, P. van Dam, E.A. Van Marck, P.B. Vermeulen, and L.Y. Dirix, Distinct molecular signature of inflammatory breast cancer by cDNA microarray analysis. Breast Cancer Res Treat, 2005. 93(3): p. 237-46.

4. Li, J., Y. Xia, Q. Wu, S. Zhu, C. Chen, W. Yang, W. Wei, and S. Sun, Outcomes of patients with inflammatory breast cancer by hormone receptor-and HER2-defined molecular subtypes: A population-based study from the SEER program. Oncotarget, 2017. 8(30): p. 49370-49379.

5. Oualla, K., H.M. El-Zawahry, B. Arun, J.M. Reuben, W.A. Woodward, H. Gamal ElDin, B. Lim, N. Mellas, N.T. Ueno, and T.M. Fouad, Novel therapeutic strategies in the treatment of triple-negative breast cancer. Ther Adv Med Oncol, 2017. 9(7): p. 493-511.

6. Pfeiffer, R.B., 3rd and W.H. Barber, Inflammatory breast cancer presenting with acute central venous thrombosis: a case report. Am Surg, 2002. 68(6): p. 579-81.

7. Kruger, S.J., Breast cancer presenting as subclavian/axillary deep vein thrombosis and upper limb lymphoedema. Ann R Coll Surg Engl, 2012. 94(2): p. e55-6.

8. Serra, R., G. Buffone, R. Montemurro, and S. de Franciscis, Axillary vein thrombosis as the first clinical manifestation of inflammatory breast cancer: report of a case. Surg Today, 2013. 43(1): p. 100-2.

9. Stein, P.D., A. Beemath, F.A. Meyers, E. Skaf, J. Sanchez, and R.E. Olson, Incidence of venous thromboembolism in patients hospitalized with cancer. Am J Med, 2006. 119(1): p. 60-8.

10. Timp, J.F., S.K. Braekkan, H.H. Versteeg, and S.C. Cannegieter, Epidemiology of cancer-associated venous thrombosis. Blood, 2013. 122(10): p. 1712-23.

11. Eichinger, S., V. Schonauer, A. Weltermann, E. Minar, C. Bialonczyk, M. Hirschl, B. Schneider, P. Quehenberger, and P.A. Kyrle, Thrombin-activatable fibrinolysis 


\section{ACCEPTED MANUSCRIPT}

inhibitor and the risk for recurrent venous thromboembolism. Blood, 2004. 103(10): p. 3773-6.

12. Bertina, R.M., N.H. van Tilburg, F. Haverkate, B.N. Bouma, P.A. von dem Borne, J.C. Meijers, W. Campbell, D. Eaton, D.F. Hendriks, and J.L. Willemse, Discovery of thrombin activatable fibrinolysis inhibitor (TAFI). J Thromb Haemost, 2006. 4(1): p. 256-7.

13. Guimaraes, A.H., M.M. Barrett-Bergshoeff, A. Gils, P.J. Declerck, and D.C. Rijken, Migration of the activation peptide of thrombin-activatable fibrinolysis inhibitor (TAFI) during SDS-polyacrylamide gel electrophoresis. J Thromb Haemost, 2004. 2(5): p. 780-4.

14. Bajzar, L., Thrombin activatable fibrinolysis inhibitor and an antifibrinolytic pathway. Arterioscler Thromb Vasc Biol, 2000. 20(12): p. 2511-8.

15. Hataji, O., O. Taguchi, E.C. Gabazza, H. Yuda, C.N. D'Alessandro-Gabazza, H. Fujimoto, Y. Nishii, T. Hayashi, K. Suzuki, and Y. Adachi, Increased circulating levels of thrombin-activatable fibrinolysis inhibitor in lung cancer patients. Am J Hematol, 2004. 76(3): p. 214-9.

16. Salman, T.D., L.; Arslan, C.; Koldaş, M.; Varol, U.; Oflazoğlu, U.; Küçükzeybek, Y.; Alacacığlu, A.; Y1lmaz, U., Thrombin activatable fibrinolysis inhibitor (TAFI), tissue factor pathway inhibitor (TFPI), and prothrombin fragment $1+2$ levels in patients with advanced colorectal cancer. Acta Oncol Tur., 2016. 49(1): p. 6-12.

17. Kaftan, O., B. Kasapoglu, M. Koroglu, A. Kosar, and S.K. Yalcin, Thrombinactivatable fibrinolysis inhibitor in breast cancer patients. Med Princ Pract, 2011. 20(4): p. 332-5.

18. Chengwei, X., M. Xiaoli, Z. Yuan, P. Li, W. Shengjiang, Y. Chao, and W. Yunshan, Plasma thrombin-activatable fibrinolysis inhibitor levels and its Thr325Ile polymorphism in breast cancer. Blood Coagul Fibrinolysis, 2013. 24(7): p. 698-703.

19. Fawzy, M.S., E.A. Mohammed, A.S. Ahmed, and A. Fakhr-Eldeen, Thrombinactivatable fibrinolysis inhibitor Thr325Ile polymorphism and plasma level in breast cancer: A pilot study. Meta Gene, 2015. 4: p. 73-84.

20. Esmon, C.T., The regulation of natural anticoagulant pathways. Science, 1987. 235(4794): p. 1348-52.

21. Kao, Y.C., L.W. Wu, C.S. Shi, C.H. Chu, C.W. Huang, C.P. Kuo, H.M. Sheu, G.Y. Shi, and H.L. Wu, Downregulation of thrombomodulin, a novel target of Snail, 


\section{ACCEPTED MANUSCRIPT}

induces tumorigenesis through epithelial-mesenchymal transition. Mol Cell Biol, 2010. 30(20): p. 4767-85.

22. ten Cate, H. and A. Falanga, Overview of the postulated mechanisms linking cancer and thrombosis. Pathophysiol Haemost Thromb, 2008. 36(3-4): p. 122-30.

23. Horowitz, N.A. and J.S. Palumbo, Mechanisms coupling thrombomodulin to tumor dissemination. Thromb Res, 2012. 129 Suppl 1: p. S119-21.

24. Zhang, Y., H. Weiler-Guettler, J. Chen, O. Wilhelm, Y. Deng, F. Qiu, K. Nakagawa, M. Klevesath, S. Wilhelm, H. Bohrer, M. Nakagawa, H. Graeff, E. Martin, D.M. Stern, R.D. Rosenberg, R. Ziegler, and P.P. Nawroth, Thrombomodulin modulates growth of tumor cells independent of its anticoagulant activity. J Clin Invest, 1998. 101(7): p. 1301-9.

25. Koutsi, A., A. Papapanagiotou, and A.G. Papavassiliou, Thrombomodulin: from haemostasis to inflammation and tumourigenesis. Int J Biochem Cell Biol, 2008. 40(9): p. 1669-73.

26. Ogawa, H., S. Yonezawa, I. Maruyama, Y. Matsushita, Y. Tezuka, H. Toyoyama, M. Yanagi, H. Matsumoto, H. Nishijima, T. Shimotakahara, T. Aikou, and E. Sato, Expression of thrombomodulin in squamous cell carcinoma of the lung: its relationship to lymph node metastasis and prognosis of the patients. Cancer Lett, 2000. 149(1-2): p. 95-103.

27. Hanly, A.M., M. Redmond, D.C. Winter, S. Brophy, J.M. Deasy, D.J. BouchierHayes, and E.W. Kay, Thrombomodulin expression in colorectal carcinoma is protective and correlates with survival. Br J Cancer, 2006. 94(9): p. 1320-5.

28. Hanly, A.M., A. Hayanga, D.C. Winter, and D.J. Bouchier-Hayes, Thrombomodulin: tumour biology and prognostic implications. Eur J Surg Oncol, 2005. 31(3): p. 21720.

29. Horowitz, N.A., E.A. Blevins, W.M. Miller, A.R. Perry, K.E. Talmage, E.S. Mullins, M.J. Flick, K.C. Queiroz, K. Shi, and C.A. Spek, Thrombomodulin is a determinant of metastasis through a mechanism linked to the thrombin binding domain but not the lectin-like domain. Blood, 2011. 118.

30. Bazzi, Z.A., D. Lanoue, M. El-Youssef, R. Romagnuolo, J. Tubman, D. CavalloMedved, L.A. Porter, and M.B. Boffa, Activated thrombin-activatable fibrinolysis inhibitor (TAFIa) attenuates breast cancer cell metastatic behaviors through inhibition of plasminogen activation and extracellular proteolysis. BMC cancer, 2016. 16: p. 328. 


\section{ACCEPTED MANUSCRIPT}

31. Kundu, N., T.L. Beaty, M.J. Jackson, and A.M. Fulton, Antimetastatic and antitumor activities of interleukin 10 in a murine model of breast cancer. J Natl Cancer Inst, 1996. 88(8): p. 536-41.

32. Hamidullah, B. Changkija, and R. Konwar, Role of interleukin-10 in breast cancer. Breast Cancer Res Treat, 2012. 133(1): p. 11-21.

33. Kozlowski, L., I. Zakrzewska, P. Tokajuk, and M.Z. Wojtukiewicz, Concentration of interleukin-6 (IL-6), interleukin-8 (IL-8) and interleukin-10 (IL-10) in blood serum of breast cancer patients. Rocz Akad Med Bialymst, 2003. 48: p. 82-4.

34. Llanes-Fernandez, L., R.I. Alvarez-Goyanes, C. Arango-Prado Mdel, J.M. AlcocerGonzalez, J.C. Mojarrieta, X.E. Perez, M.O. Lopez, S.F. Odio, R. CamachoRodriguez, M.E. Guerra-Yi, V. Madrid-Marina, R. Tamez-Guerra, and C. RodriguezPadilla, Relationship between IL-10 and tumor markers in breast cancer patients. Breast, 2006. 15(4): p. 482-9.

35. Fouad, T.M., T. Kogawa, J.M. Reuben, and N.T. Ueno, The role of inflammation in inflammatory breast cancer. Adv Exp Med Biol, 2014. 816: p. 53-73.

36. Mohamed, M.M., Al-Raawi, D., Sabet, S.F., El-Shinawi, M. , Inflammatory breast cancer: new factors contribute to disease etiology (Review). Journal of Advanced Research, 2014. 5(5): p. 525-536.

37. Sabet, S., S.K. El-Sayed, H.T. Mohamed, M. El-Shinawi, and M.M. Mohamed, Inflammatory breast cancer: High incidence of GCC haplotypes $(-1082 A / G,-819 T / C$, and $-592 \mathrm{~A} / \mathrm{C}$ ) in the interleukin-10 gene promoter correlates with over-expression of interleukin-10 in patients' carcinoma tissues. Tumour Biol, 2017. 39(7): p. 1010428317713393.

38. Komnenov, D., C.A. Scipione, Z.A. Bazzi, J.J. Garabon, M.L. Koschinsky, and M.B. Boffa, Pro-inflammatory cytokines reduce human TAFI expression via tristetraprolinmediated mRNA destabilisation and decreased binding of HuR. Thromb Haemost, 2015. 114(2): p. 337-49.

39. Nouh, M.A., M.M. Mohamed, M. El-Shinawi, M.A. Shaalan, D. Cavallo-Medved, H.M. Khaled, and B.F. Sloane, Cathepsin B: a potential prognostic marker for inflammatory breast cancer. J Transl Med, 2011. 9: p. 1.

40. Zainab A. Bazzi, D.L., Mouhanned El-Youssef, Rocco Romagnuolo, Janice Tubman, Dora Cavallo-Medved, Lisa A. Porter and Michael B. Boffa, Activated thrombinactivatable fibrinolysis inhibitor (TAFIa) attenuates breast cancer cell metastatic 


\section{ACCEPTED MANUSCRIPT}

behaviors through inhibition of plasminogen activation and extracellular proteolysis. BMC cancer, 2016. 328(16).

41. Liebertz, D.J., M.G. Lechner, R. Masood, U.K. Sinha, J. Han, R.K. Puri, A.J. Correa, and A.L. Epstein, Establishment and Characterization of a Novel Head and Neck Squamous Cell Carcinoma Cell Line USC-HN1. Head \& Neck Oncology, 2010. 2(1): p. 5.

42. Boffa, J.H.H.L.M.G.B.Z.S.L.S.C.S.M.L.K.a.M.B., Identification of human thrombinactivatable fibrinolysis inhibitor in vascular and inflammatory cells Blood Coagulation, Fibrinolysis and Cellular Haemostasis, 2011. 105: p. 11.

43. Ibrahim, S.A., R. Gadalla, E.A. El-Ghonaimy, O. Samir, H.T. Mohamed, H. Hassan, B. Greve, M. El-Shinawi, M.M. Mohamed, and M. Gotte, Syndecan-1 is a novel molecular marker for triple negative inflammatory breast cancer and modulates the cancer stem cell phenotype via the IL-6/STAT3, Notch and EGFR signaling pathways. Mol Cancer, 2017. 16(1): p. 57.

44. El-Shinawi, M., H.T. Mohamed, E.A. El-Ghonaimy, M. Tantawy, A. Younis, R.J. Schneider, and M.M. Mohamed, Human cytomegalovirus infection enhances NFkappaB/p65 signaling in inflammatory breast cancer patients. PLoS One, 2013. 8(2): p. e55755.

45. El-Ghonaimy, E.A., S.A. Ibrahim, A. Youns, Z. Hussein, M.A. Nouh, T. ElMamlouk, M. El-Shinawi, and M.M. Mohamed, Secretome of tumor-associated leukocytes augment epithelial-mesenchymal transition in positive lymph node breast cancer patients via activation of EGFR/Tyr845 and NF-kappaB/p65 signaling pathway. Tumour Biol, 2016. 37(9): p. 12441-12453.

46. Mohamed, M.M., Monocytes conditioned media stimulate fibronectin expression and spreading of inflammatory breast cancer cells in three-dimensional culture: A mechanism mediated by IL-8 signaling pathway. Cell Commun Signal, 2012. 10(1): p. 3.

47. Sole, X., Guino, E., Valls, J., Iniesta, R., Moreno, V., SNPStats: a web tool for the analysis of association studies. Bioinformatics, 2006. 22: p. 2.

48. Andersen, S.W., A. Trentham-Dietz, J.D. Figueroa, L.J. Titus, Q. Cai, J. Long, J.M. Hampton, K.M. Egan, and P.A. Newcomb, Breast cancer susceptibility associated with rs 1219648 (fibroblast growth factor receptor 2) and postmenopausal hormone therapy use in a population-based United States study. Menopause, 2013. 20(3): p. 354-8. 


\section{ACCEPTED MANUSCRIPT}

49. El-Shinawi, M., H.T. Mohamed, H.H. Abdel-Fattah, S.A. Ibrahim, M.S. ElHalawany, M.A. Nouh, R.J. Schneider, and M.M. Mohamed, Inflammatory and Noninflammatory Breast Cancer: A Potential Role for Detection of Multiple Viral DNAs in Disease Progression. Ann Surg Oncol, 2016. 23(2): p. 494-502.

50. Mohamed, M.M., E.A. El-Ghonaimy, M.A. Nouh, R.J. Schneider, B.F. Sloane, and M. El-Shinawi, Cytokines secreted by macrophages isolated from tumor microenvironment of inflammatory breast cancer patients possess chemotactic properties. Int J Biochem Cell Biol, 2014. 46: p. 138-47.

51. Lara-Medina, F., V. Perez-Sanchez, D. Saavedra-Perez, M. Blake-Cerda, C. Arce, D. Motola-Kuba, C. Villarreal-Garza, A.M. Gonzalez-Angulo, E. Bargallo, J.L. Aguilar, A. Mohar, and O. Arrieta, Triple-negative breast cancer in Hispanic patients: high prevalence, poor prognosis, and association with menopausal status, body mass index, and parity. Cancer, 2011. 117(16): p. 3658-69.

52. Garand, M.L., Joellen H.H.; Zagorac, Branislava; Koschinsky, Marlys L.; Boffa, Michael B, Regulation of the gene encoding human thrombin-activatable fibrinolysis inhibitor by estrogen and progesterone. Blood Coagulation \& Fibrinolysis, 2013. 24(4): p. 12.

53. Mosnier, L.O., J.C. Meijers, and B.N. Bouma, Regulation of fibrinolysis in plasma by TAFI and protein $C$ is dependent on the concentration of thrombomodulin. Thromb Haemost, 2001. 85(1): p. 5-11.

54. Chun-Te Wu, Y.-H.C., Paul- Yang Lin, Wen-Cheng Chen and Miao-Fen Chen, Thrombomodulin expression regulates tumorigenesis in bladder cancer. BMC cancer, 2014. 375(14).

55. Menschikowski, M., A. Hagelgans, O. Tiebel, M. Vogel, G. Eisenhofer, and G. Siegert, Regulation of thrombomodulin expression in prostate cancer cells. Cancer Lett, 2012. 322(2): p. 177-84.

56. Chavey, C., F. Bibeau, S. Gourgou-Bourgade, S. Burlinchon, F. Boissiere, D. Laune, S. Roques, and G. Lazennec, Oestrogen receptor negative breast cancers exhibit high cytokine content. Breast Cancer Res, 2007. 9(1): p. R15.

57. Allen, S.G., Y.C. Chen, J.M. Madden, C.L. Fournier, M.A. Altemus, A.B. Hiziroglu, Y.H. Cheng, Z.F. Wu, L. Bao, J.A. Yates, E. Yoon, and S.D. Merajver, Macrophages Enhance Migration in Inflammatory Breast Cancer Cells via RhoC GTPase Signaling. Sci Rep, 2016. 6: p. 39190. 


\section{ACCEPTED MANUSCRIPT}

58. Rui Wang, M.L., Haiquan Chen, Sufeng Chen, Xiaoyang Luo, Ying Qin and Jie Zhang, Increased IL-10 mRNA expression in tumor-associated macrophage correlated with late stage of lung cancer. Journal of Experimental \& Clinical Cancer Research, 2011. 60(32).

59. Pang, H., C. Zhang, F. Liu, X. Gong, X. Jin, and C. Su, Reduced thrombin activatable fibrinolysis inhibitor and enhanced inflammatory markers in ACS. Minerva Cardioangiol, 2016.

\section{Figures legends:}

Figure 1: $C P B 2$ and $T H B D$ mRNA expression in non-IBC and IBC patients' breast carcinoma tissues. Bars represent $C P B 2$ mRNA expression measured by RT-PCR, (A) $C P B 2$ is down-regulated in normal compared to carcinoma tissues, (B) Carcinoma tissues of IBC, overexpress $C P B 2$ mRNA compared to non-IBC (C and D) Carcinoma tissues of TN patients overexpress $C P B 2$ in non-IBC (C) and IBC (D). Bars represent THBD mRNA expression in (E) normal breast and carcinoma breast tissues; (F) non-IBC compared to IBC carcinoma tissues, with significant down-regulation in IBC; $(\mathrm{G} \& \mathrm{H})$ carcinoma tissues of TN and HP subgroups of non-IBC $(\mathrm{G})$ and $\operatorname{IBC}(\mathrm{H})$. *indicates a significant $p$ value, as determined by Student's t test.

Figure 2: mRNA and protein expression of IL-10 in non-IBC and IBC patients' carcinoma tissues. Bars represent (A) RT-PCR results showing down-regulation of IL10 mRNA expression in normal breast tissues as compared to carcinoma breast tissues. (B) IL10 mRNA highly expressed by IBC as compared to non-IBC carcinoma tissues. (C) Nonsignificant difference between the level of expression of ILIO mRNA in TN and HP subgroups of non-IBC patients. (D) Significant increase in the expression of ILIO by TN subgroup compared to HP subgroup in IBC patients. (E) Relative density value of IL-10 protein assessed by western blot and normalized against $\beta$-tubulin, statistical analysis 


\section{ACCEPTED MANUSCRIPT}

revealed that IL-10 protein was significantly over-expressed in IBC compared to non-IBC carcinoma tissues. (F) Representative IL-10 immunoblots of non-IBC carcinoma tissues (G) Statistical analysis of immunoblots revealed a non-significant difference in the IL-10 expression in TN and HP subgroups. (H) Representative IL-10 immunoblots in the carcinoma tissues of IBC patients. (I) Statistical analysis revealed high level of expression of IL-10 in TN compared to HP carcinoma tissues *indicates a significant $p$ value, as determined by Student's t test.

Figure 3: $C P B 2$ and $I L 10 \mathrm{mRNA}$ expression positively correlate with lymphovascular invasion in IBC tissues. (A) Representative microscopic fields of $\mathrm{H} \& \mathrm{E}$ stained paraffin embedded tissue sections in IBC tissues showing dermal lymphovascular invasion (magnification: middle panel 10X, while left and right panel 40X). Bars represent the expression of $C P B 2(\mathrm{~B})$ and $I L 10(\mathrm{C})$ in the presence of lymphovascular invasion. *indicates a significant $p$ value, as determined by Chi square test.

Figure 4: $C P B 2$ and $I L 10 \mathrm{mRNA}$ expression positively correlates with the infiltration CD14 $^{+}$cells in IBC carcinoma tissues. (A) Representative fields of microscopic images showing immunostaining (brown color) of higher expression of CD14 in IBC $(n=15)$ as compared to non-IBC $(n=15)$ carcinoma tissues. (B) Bars represent the infiltration of CD14 cells in non-IBC and IBC carcinoma tissues. (C\&D) Scatter plots showed that $C P B 2$ and IL10 mRNA expression positively correlates with the infiltration CD14 ${ }^{+}$cells in IBC carcinoma tissues. *indicates a significant $p$ value, as determined by Student's t test.

Figure 5: Different concentrations of recombinant IL-10 stimulate the mRNA expression of $C P B 2$ in SUM149 IBC cell line. RT-PCR analysis detected (A) Significant increase in the expression of $C P B 2$ mRNA by SUM-149 after stimulation with different concentrations of recombinant human IL-10 for $24 \mathrm{~h}$. (B) Non-significant change in the 


\section{ACCEPTED MANUSCRIPT}

expression of THBD mRNA by MDA-MB-231 and SUM-149. *indicates a significant $p$ value, as determined by Student's t test.
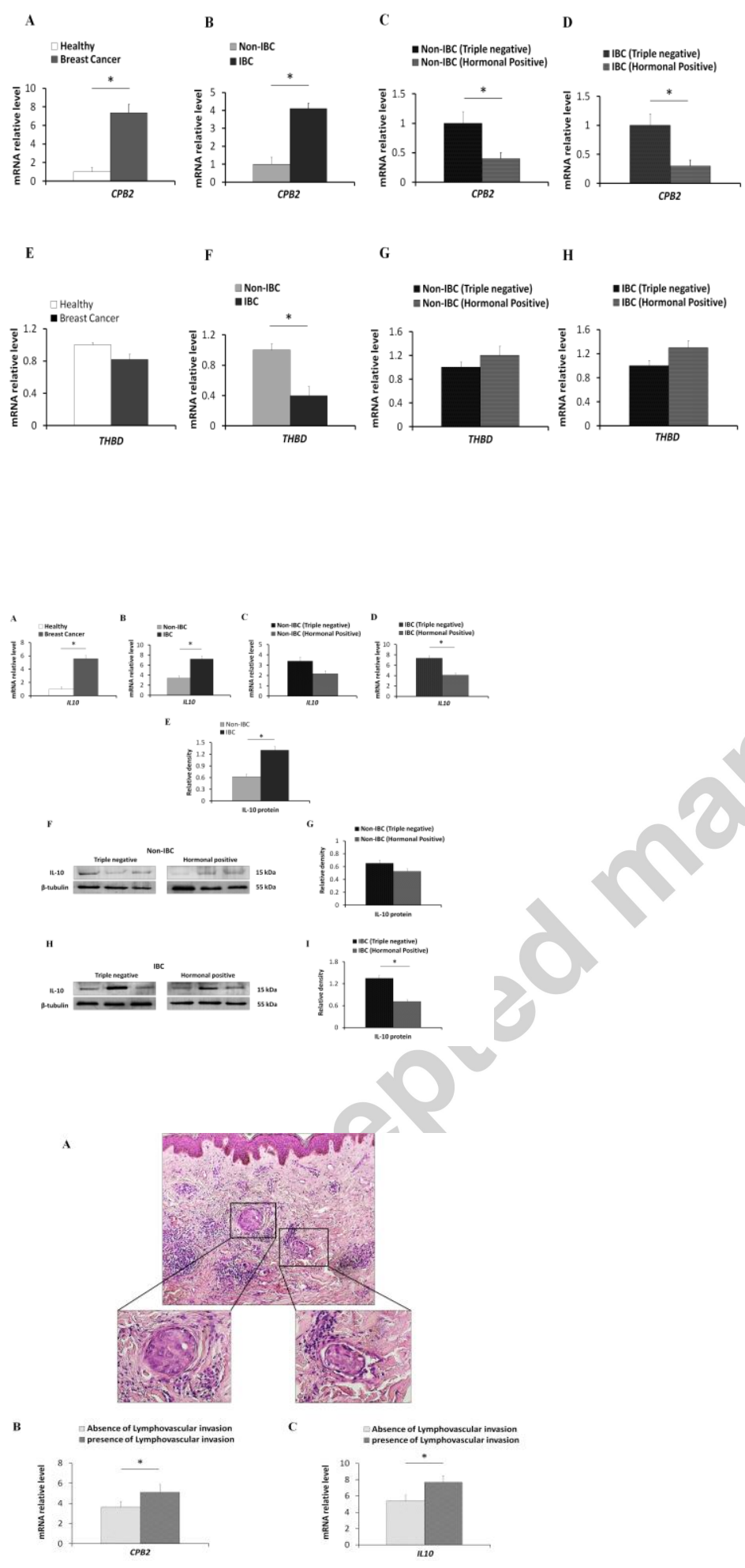

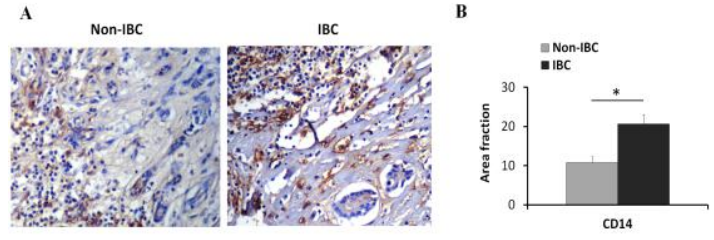

C

D
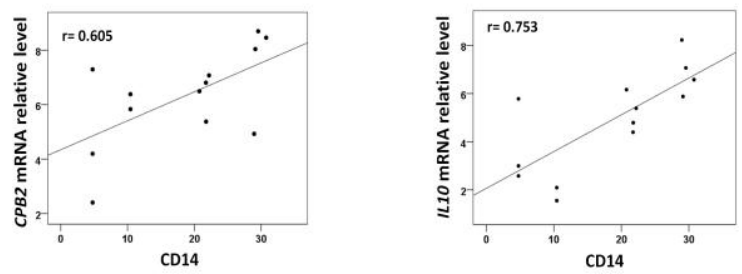

A

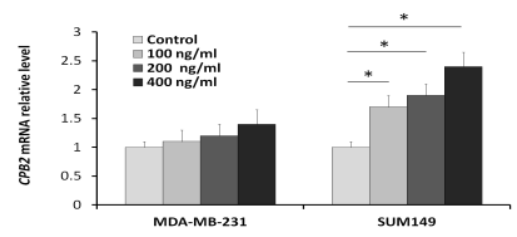

B

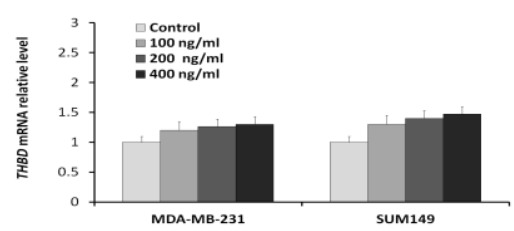




\section{Tables:}

Table 1: Clinical and pathological characterization of non-IBC versus IBC patients

\begin{tabular}{|c|c|c|c|}
\hline Characteristic & $\begin{array}{c}\text { Non-IBC } \\
(\mathrm{N}=91)\end{array}$ & $\begin{array}{c}\text { IBC } \\
(\mathrm{N}=44)\end{array}$ & $P$ value \\
\hline \multicolumn{4}{|l|}{ Age [year] } \\
\hline $\begin{array}{l}\text { Range } \\
\text { Mean } \pm \text { SD } \\
\text { NA }\end{array}$ & $\begin{array}{c}27-78 \\
51.98 \pm 10.969 \\
1\end{array}$ & $\begin{array}{c}29-72 \\
49.34 \pm 11.994 \\
0\end{array}$ & $0.223^{\mathrm{a}}$ \\
\hline \multicolumn{4}{|l|}{ Tumor Size [cm] } \\
\hline $\begin{array}{l}\text { Mean } \pm \text { SD } \\
\leq 4 \\
>4\end{array}$ & $\begin{array}{c}4.6 \pm 3.5 \\
58(63.8 \%) \\
33(36.2 \%)\end{array}$ & $\begin{array}{l}5.73 \pm 2.71 \\
16(36.4 \%) \\
28(63.6 \%)\end{array}$ & $0.003^{* \mathrm{a}}$ \\
\hline \multicolumn{4}{|l|}{ Pathology } \\
\hline $\begin{array}{l}\text { Ductal Carcinoma In Situ } \\
\text { Invasive Ductal Carcinoma } \\
\text { Invasive Lobular Carcinoma }\end{array}$ & $\begin{array}{c}10(11 \%) \\
73(81.3 \%) \\
7(7.7 \%)\end{array}$ & $\begin{array}{c}0(0 \%) \\
41(93.2 \%) \\
3(6.8 \%)\end{array}$ & $0.069^{\mathrm{a}}$ \\
\hline \multicolumn{4}{|l|}{$\begin{array}{r}\text { Tumor grade } \\
\end{array}$} \\
\hline $\begin{array}{l}\text { G1 } \\
\text { G2 } \\
\text { G3 }\end{array}$ & $\begin{array}{c}4(4.4 \%) \\
74(80.2 \%) \\
14(15.4 \%) \\
\end{array}$ & $\begin{array}{c}0(0 \%) \\
35(79.5 \%) \\
9(20.5 \%) \\
\end{array}$ & $0.304^{b}$ \\
\hline Axillary Lymph Node Metastasis & & 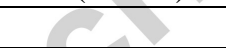 & \\
\hline $\begin{array}{l}\leq 4 \\
>4\end{array}$ & $\begin{array}{l}64(70.3 \%) \\
27(29.7 \%)\end{array}$ & $\begin{array}{l}14(31.8 \%) \\
30(68.2 \%)\end{array}$ & $0.002^{* \mathrm{~b}}$ \\
\hline \multicolumn{4}{|l|}{ Lymphovascular invasion } \\
\hline $\begin{array}{l}\text { Negative } \\
\text { Positive }\end{array}$ & $\begin{array}{l}75(82.4 \%) \\
16(17.6 \%)\end{array}$ & $\begin{array}{l}14(31.8 \%) \\
30(68.2 \%)\end{array}$ & $0.001^{* \mathrm{~b}}$ \\
\hline \multicolumn{4}{|l|}{ ER } \\
\hline $\begin{array}{l}\text { Negative } \\
\text { Positive } \\
\text { NA }\end{array}$ & $\begin{array}{l}20(45.5 \%) \\
15(34.1 \%) \\
9(20.5 \%)\end{array}$ & $\begin{array}{l}35(38.5 \%) \\
38(41.8 \%) \\
18(19.8 \%)\end{array}$ & $0.668^{b}$ \\
\hline \multicolumn{4}{|l|}{$\mathbf{P R}$} \\
\hline $\begin{array}{l}\text { Negative } \\
\text { Positive } \\
\text { NA }\end{array}$ & $\begin{array}{l}19(43.2 \%) \\
15(34.1 \%) \\
10(22.7 \%)\end{array}$ & $\begin{array}{l}42(46.2 \%) \\
31(34.1 \%) \\
18(19.8 \%)\end{array}$ & $0.913^{b}$ \\
\hline \multicolumn{4}{|l|}{ Her-2 } \\
\hline $\begin{array}{l}\text { Negative } \\
\text { Positive } \\
\text { NA }\end{array}$ & $\begin{array}{l}21(47.7 \%) \\
13(29.5 \%) \\
10(22.7 \%)\end{array}$ & $\begin{array}{l}44(48.4 \%) \\
29(31.9 \%) \\
18(19.8 \%)\end{array}$ & $0.915^{b}$ \\
\hline $\begin{array}{l}\text { Data are reported as means } \pm \text { SD } \\
\text { a Student's t-test. } \\
{ }^{\text {b }} \text { Chi square test. } \\
* \text { Significant } \boldsymbol{p} \text { value }(p<0.05) \\
\text { NA = not available }\end{array}$ & & & \\
\hline
\end{tabular}




\section{ACCEPTED MANUSCRIPT}

Table 2: Genotype and allele frequencies of CPB2 (Thr325Ile) polymorphism among studied groups using SNPstat software.

\begin{tabular}{|c|c|c|c|c|c|c|c|c|}
\hline $\begin{array}{c}C P B 2 \\
\text { Genotypes }\end{array}$ & $\begin{array}{c}\text { Healthy } \\
(n=50) \\
\text { No }(\%)\end{array}$ & $\begin{array}{c}\text { Breast cancer } \\
(\mathbf{n}=135) \\
\text { No }(\%)\end{array}$ & $\begin{array}{c}\text { Odds } \\
\text { ratio } \\
(95 \% \mathrm{CI}) \\
\end{array}$ & $\begin{array}{c}P \text { - } \\
\text { value }\end{array}$ & $\begin{array}{c}\text { Non-IBC } \\
(n=50) \\
\text { No }(\%) \\
\end{array}$ & $\begin{array}{c}\text { IBC } \\
(n=135) \\
\text { No }(\%)\end{array}$ & $\begin{array}{c}\text { Odds } \\
\text { ratio } \\
(95 \% \mathrm{CI}) \\
\end{array}$ & $\begin{array}{c}P \text { - } \\
\text { value }\end{array}$ \\
\hline Thr/Thr (CC) & $25(50)$ & $33(24.4)$ & 1.00 & & $23(25.3)$ & $\begin{array}{c}10 \\
(22.7) \\
\end{array}$ & 1.00 & \\
\hline Thr/Ile (CT) & $17(34)$ & $59(43.7)$ & $\begin{array}{c}0.38(0.18- \\
0.80)\end{array}$ & $0.003 *$ & 39 (42.9) & $\begin{array}{c}20 \\
(45.5)\end{array}$ & $\begin{array}{c}0.94 \\
(0.41- \\
2.17) \\
\end{array}$ & 0.94 \\
\hline Ile/Ile (TT) & $8(16)$ & 43 (31.9) & $\begin{array}{l}0.25(0.10- \\
0.61)\end{array}$ & $0.003^{*}$ & $29(31.9)$ & $\begin{array}{c}14 \\
(31.8)\end{array}$ & $\begin{array}{c}1.11 \\
(0.42- \\
2.95) \\
\end{array}$ & 0.94 \\
\hline $\begin{array}{l}\text { Thr/Ile }(\mathrm{CT})+ \\
\text { Ile/Ile (TT) }\end{array}$ & $25(50)$ & $102(75.6)$ & $\begin{array}{c}0.32(0.16- \\
0.64)\end{array}$ & $0.001 *$ & 68 (74.7) & $34(77.3)$ & $\begin{array}{l}1.15 \\
(0.49- \\
2.69) \\
\end{array}$ & 0.75 \\
\hline$C P B 2$ alleles & & & & & & & & \\
\hline $\mathrm{C}$ & $67(67)$ & $125(46)$ & & \multirow{2}{*}{$0.01 *$} & $48(55)$ & $97(53)$ & & \multirow{2}{*}{0.86} \\
\hline $\mathrm{T}$ & $33(33)$ & $145(54)$ & & & $40(45)$ & $85(47)$ & 8 & \\
\hline
\end{tabular}

